УДК 373.1:94(100)

DOI 10.31494/2412-9208-2019-1-1-245-254

\title{
Conditions of formation of professional competence in pedagogical practice of future history teachers
}

\section{Умови формування професійної компетентності в педагогічній практиці підготовки майбутніх учителів історії}

\author{
Andriy Hrytsenko, \\ Candidate of Pedagogical Sciences, \\ Senior Lecturer \\ Glukhiv National Pedagogical \\ University named after Alexander \\ Dovzhenko \\ 24 Kyiv-Moscow St., \\ Gluhov, Sumy region, 41400
} https://orcid.org/0000-0002-9107-1394 grikand@ukr.net

\author{
Андрій Гриценко, \\ кандидат педагогічних наук, \\ старший викладач
}

\author{
Глухівський національний \\ педагогічний університет імені \\ Олександра Довженка \\ вул. Києво-Московська, 24 \\ м. Глухів, Сумська обл., 41400
}

\section{Original manuscript received January 27, 2019}

Revised manuscript accepted April 19, 2019

\begin{abstract}
The author in the article analyzes the basic theoretical provisions of the conditions for the formation of professional competence among future teachers of history and presents the main approaches on this issue, which have developed in modern pedagogical and psychological literature. At the same time, attention was drawn to the differences between the two interrelated concepts of "competence" and "competence", as well as the three-component structure of the competence system in education, which includes key or basic, general-sectoral and vocational-specialized (subject) competencies acquired while studying one or another discipline and defining the term "professional competence".

In the article, the main features of professional competence are highlighted: the need for knowledge formation, provided they are aware of their significance for future professional activities, a set of operational skills; the development of an algorithm for the implementation of professional exercises and the ability to creativity in the performance of professional tasks. This made it possible to determine the conditions for the formation of professional competence for future teachers in the course of their continuous and systematic activities if they have the appropriate professional qualities that contribute to this activity and general abilities based on knowledge, experience, values acquired through learning, upbringing, integration into the space of social and cultural relations.

In addition, the psychological aspects of the formation of students of institutions of higher education of the indicated competence, which allows to significantly improve the effectiveness of the educational process during the training of future specialists, which accompanies the process of assimilation of theoretical foundations, means and methods of fulfilling professional tasks, can be considerably improved; ability to analyze, predict and independently choose means and means of action in certain specific situations; the ability to self-development and self-realization in the context of mastering
\end{abstract}


Серія: Педагогічні науки. - Вип.1. - Бердянськ : БДПУ, 2019. - 406 с.

modern scientific achievements and their implementation and positive attitude to their future professional activities.

Key words: competence approach, history, competences, professional competence, future teachers, professional training, professional educational qualifications.

Вступ. Розвиток сучасної освіти базується саме на компетентнісному підході як одному із стратегічних напрямів державної політики в освітній сфері та головним положенням модернізації структури, змісту та організації освіти. Тому сучасний випускник закладу вищої освіти - майбутній учитель має не лише володіти вміннями виконувати операції, а й достатнім рівнем сформованості цілого ряду компетентностей, серед яких одна з найважливіших - професійна.

Методи дослідження. У процесі аналізу історико-педагогічної літератури нами встановлено, що питання формування професійної компетентності в майбутніх педагогів активно досліджувалось українськими вченими в останні десятиліття. Зокрема, аспекти розвитку професійної компетентності та критерії діагностики їі рівнів сформованості досліджували В. Адольф, В. Боголюбов, В. Бондар, О. Заблоцька, О. Локшина та О. Савченко (Адольф, 1998; Боголюбов, 2014; Бондар, 2008; Заблоцька, 2008; Локшина, 2009; Савченко, 2011). Особливості формування предметно-історичних компетентностей вивчали К. Баханов, В. Власов, Ю. Малієнко, О. Пометун та Г. Фрейман (Баханов, 2008; Власов, 2010; Малієнко, 2014, Пометун, 2004; Фрейман, 2004). У той же час питання формування професійної компетентності в процесі підготовки майбутніх учителів історії досліджено в сучасній науці недостатньо.

Метою статті $\epsilon$ визначення основних підходів до процесу формування професійної компетентності під час підготовки майбутніх учителів історії.

Результати дискусії. В українській науці, на відміну від деяких зарубіжних підходів, після дискусії 2003-2006 років прийнято розрізняти поняття "компетентність" та “компетенція" як два взаємопов'язані терміни, які означають, що людина володіє відповідною компетенцією, а також досягнення нею здатності через певні особисті якості до ефективної діяльності (компетентність) та делегування особі певних повноважень практично застосовує, правильно вирішуючи певні конкретні завдання (компетенція). Аналізуючи питання в контексті професійної підготовки педагогів, дослідниця О. Савченко розглядає компетентність як інтегровану категорію, що “виражає сформовану насамперед засобами освіти здатність індивідів успішно розв'язувати загальні і специфічні проблеми як у трудовій діяльності, так і в суспільному житті як громадянин (Савченко, 2011: 20).

Більшість науковців (О. Пометун, А. Хуторськой та ін. (Пометун, 2004; Хуторськой, 2003)) вважають, що система компетентностей в освіті має трискладову структуру:

- загальні або ключові чи базові (комплекс компетентностей) як здатність до складних поліфункціональних та поліпредметних видів 
діяльності;

- загально-галузеві (засвоєння змісту тієї чи іншої галузі знання або певного виду діяльності);

- предметні або професійно-спеціалізовані компетентності, які набуваються впродовж вивчення тієї чи іншої навчальної дисципліни як сума знань, умінь та характерних рис у межах навчального предмета.

Російська дослідниця І. Зимня (Зимняя, 2004), називає дещо іншу класифікацію трьох груп компетентностей: особистісні, що стосуються особистості як суб'єкта життєдіяльності; комунікативні, що стосуються взаємодії людини з іншими людьми, діяльнісні, які стосуються діяльності людини, яка проявляється у всіх її типах і формах.

Таким чином, ключові компетентності можна застосовувати в широкій сфері діяльності людини, а розвиток загальних компетентностей передбачає формування предметно-спеціальних компетентностей, які згодом трансформуються в професійні (історичні) компетентності. Формування професійної компетентності в майбутніх учителів відбувається за умови їх неперервної та системної діяльності за наявності в них відповідних професійних якостей, які сприяють цій діяльності, та загальних здібностей, що ґрунтуються на знаннях, досвіді, цінностях, набутих завдяки навчанню, вихованню, інтеграції в простір соціальних і культурних відношень, міжособистісної інтеграції та спілкування. На нашу думку, чи не найважливішим аспектом цього процесу $€$ організація психологічного супроводу фрормування професійних навичок у студентів, їх комунікації, здатних створити певну система психологічних механізмів, що сприяюють усвідомленню і критичному опрацюванню необхідної інформації (Гриценко, 2018: 60).

Наразі професійні компетентності прийнято поділяти на предметно-спеціальні та загальні компетентності. Відповідно основні компетентнісні характеристики рівня щодо навчання та/або професійної діяльності представлено поняттям “інтегральна компетентність” як узагальнений опис кваліфікаційного рівня в Національній рамці кваліфікацій України (Національна рамка кваліфікацій, 2011). Дослідниками вже напрацьовані різні види та структура професійних компетентностей за окремими навчальними спеціальностями, які можуть бути використані при розробленні освітніх програм конкретними закладами вищої освіти (Кремень, 2014).

Відповідно предметно-спеціальні компетентності майбутніх учителів історії включають такі складові: хронологічна, просторова, інформаційна, логічна, аксіологічна компетенції (Пометун, 2004: 106-107), фрормуючи кваліфрікацію випускника (рис. 1). 


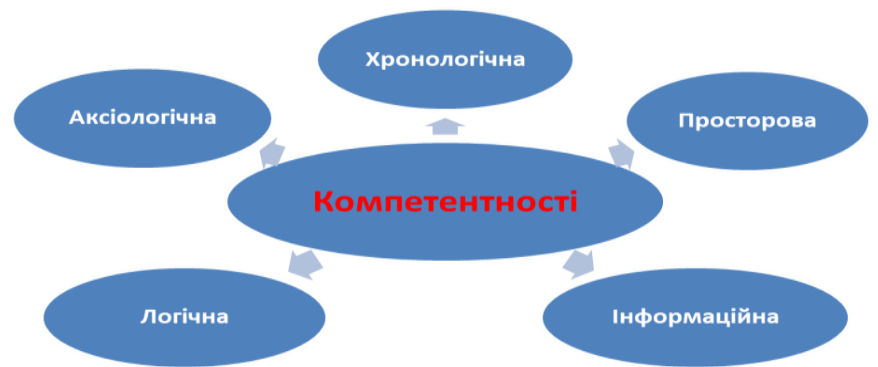

Рис 1. Перелік компетентностей майбутніх учителів історії

Формування предметно-історичної компетентності майбутніх учителів історії - це одна з найважливіших складових сучасної вищої історичної освіти, а цей факт вимагає подальшого вдосконалення системи підготовки майбутніх учителів історії як особистості, здатної вирішувати важливі й необхідні загальнокультурні та суспільно-гуманітарні завдання, які постають перед сучасним суспільством. Відповідно до цього доцільним, на наш погляд, $є$ вдосконалення змісту, структури, форм і методів професійної підготовки майбутніх учителів історії, визначення педагогічних умов підвищення формування їх фрахової компетентності. У сучасних умовах інтенсивного розвитку інформаційного суспільства унікальні можливості для організації освітнього процесу надає всесвітня мережа Інтернет. При цьому важливе значення для фрормування професійної компетентності в майбутніх учителів історії має організація роботи 3 інформаційними ресурсами віртуальних бібліотек, електронними або мережевими хрестоматіями, а також електронні сторінки 3 текстами і графічними зображеннями енциклопедичного характеру, як, наприклад, Вікіпедія - відкрита українська вільна енциклопедія (Гриценко, 2018: 283).

Тобто, важливе значення набувають також компетентності, які не пов'язані з предметною галуззю, але відіграють важливу роль у підготовці фахівця. Серед них можна виділити загальнокультурну компетентність, яка передбачає здатність учнів аналізувати та оцінювати досягнення національної та світової культури, орієнтуватися в культурному та духовному контексті сучасного суспільства, застосовувати методи самовихованні, орієнтовані на загальнолюдські цінності (Державний стандарт базової і повної середньої освіти, 2011). Науковець О. Величко звертає увагу, що "характеристика освітнього процесу надає можливість формувати такий рівень професійної та громадської компетентності, який задовольняє потреби громадян, підприємств і організацій, суспільства та держави" (Величко, 2003: 284). На думку дослідниці Ю. Малієнко, формування громадянської компетентності в ході виховання толерантності сприяє становленню здатності учня активно, відповідально та ефективно реалізовувати права та обов'язки з метою розвитку демократичного суспільства (Малієнко, 2016: 208). Тобто процес формування предметних компетентностей доцільно також поєднувати із 
загальними компетентностями як передумову організації освітнього процесу, орієнтованого на розвиток особистості.

В умовах багатоаспектності поняття "професійної компетентності" тлумачиться науковцями по-різному. На думку Б.Гершунського, під професійною компетентністю слід розуміти певний рівень освіченості фахівця (Гершунский, 1998).

За словами Ю. Афанасьєва, професійна компетентність - це сукупність професійних знань, умінь і навичок, а також засобів виконання професійної діяльності (Афанасьєв, 1990). У Ю. Татура зустрічаємо таке визначення професійної компетентності: "компетентність спеціаліста 3 вищою освітою - це проявлені ним на практиці прагнення і здатності (готовність) реалізувати свій потенціал (знання, уміння, досвід, особистісні якості та ін.) для успішної творчої (продуктивної) діяльності в професійній і соціальній сфері, усвідомлюючи іï соціальну значущість і особисту відповідальність за результати цієї діяльності, необхідність її постійного удосконалення" (Татура, 2004). О. Дубасенюк характерною рисою професійної компетентності майбутнього вчителя називає сукупність його умінь структурувати наукові та практичні знання для ефективного вирішення професійних завдань (Дубасенюк, 2007: 636]. А на думку А. Маркової, у ході педагогічної діяльності на високому рівні, педагогічного спілкування формується професійна компетентність, що проявляється в результатах навчання та виховання школярів (Маркова, 1996). В. Адольф стверджує, що “професійна компетентність - це складне утворення, яке вміщує комплекс знань, умінь, властивостей і якостей особистості, що забезпечують варіативність, оптимальність та ефективність побудови освітнього процесу" (Адольф, 1998). Дослідниця С. Кара професійну компетентність майбутнього вчителя тлумачить як сукупність професійних знань, умінь і навичок, важливих якостей особистості, її прагнення на високому рівні здійснювати навчально-виховну, науково-методичну та соціально-педагогічну діяльність, здатність до самооцінки особистісних властивостей і якостей, а також регулювання процесу професійного становлення (Кара, 2012).

У педагогічному енциклопедичному словнику це поняття характеризується інтегративним переліком ділових та особистісних якостей фахівця, які мають відображати рівень знань, умінь, досвіду достатніх для досягнення мети з певного виду професійної діяльності, а також моральну позицію спеціаліста (Гончаренко, 2011: 383).

Таким чином, більшість науковців до складу професійної компетентності включають певні ознаки, серед яких можна виділити: необхідність формування знань за умови усвідомлення їх значущості для майбутньої професійної діяльності; набір операційних умінь; напрацювання алгоритму виконання професійних вправ та здатність до творчості під час виконання професійних завдань.

Погоджуючись із вищезазначеним, ми вважаємо, що поняття “професійної компетентності необхідно поєднати 3 практичною та особистісною готовністю особистості до якісного виконання професійної діяльності, тобто реалізація особистісного потенціалу зі здатністю 
застосовувати наявні знання, уміння і навички для досягнення високих результатів у професійній діяльності.

Іноді термін “професійної компетентності" замінюється поняттям "професійні освітні кваліфікації" (від англ. - "Professional educational qualifications"), що означає певні освітні кваліфікації, здобуті випускником у результаті засвоєння професійних освітніх програм як готовність виходити на ринок праці для здійснення своєї професійної діяльності. Подібне поняття “академічні кваліфікації (ступені)”, на відміну від професійних освітніх кваліфікацій, орієнтоване на подальше навчання або професійні кар'єрні кваліфікації, які надаються роботодавцями у сфрері праці (Луговий, 2010; Таланова, 2010).

Відповідно саме на переформатування ролі випускників, які мають не лише глибокі теоретичні знання, але й здатні самостійно застосовувати їх у нестандартних, постійно змінюваних життєвих ситуаціях в умовах переходу від суспільства знань до суспільства життєво компетентних громадян, зосереджує увагу Національна стратегія розвитку освіти в Україні на період до 2021 року, затверджена Указом Президента України від 25 червня 2013 року за № 344/2013. У методичних рекомендаціях щодо розроблення стандартів вищої освіти, затверджених Наказом Міністерства освіти і науки України від 21 грудня 2017 № 1648, зазначається, що “компетентності випускника відображають погляд зовнішніх замовників: роботодавців, професійних асоціацій, випускників тощо на освітню та/або професійну підготовку і мають максимізувати здатність до працевлаштування" (Методичні рекомендації, 2017).

Висновки. Узагальнивши різні визначення дослідників, ми дійшли висновку, що професійну компетентність можна визначити як сукупність знань, умінь, навичок, особистісних якостей майбутнього фахівця, необхідних для забезпечення ефективної професійної діяльності. Цей процес у майбутніх учителів історії відбувається за умови: засвоєння теоретичних основ, засобів і методів виконання професійних завдань; уміння аналізувати, прогнозувати свою діяльність та самостійно обирати засоби та способи дії в певних конкретних ситуаціях; здатність до саморозвитку та самореалізації за умов опанування сучасних наукових досягнень та їх упровадження i позитивного ставлення до своєї майбутньої професійної діяльності. Відповідно за умови подальшого опрацювання названих критеріїв та принципів, тобто неухильного упровадження теоретичних основ на практиці в освітній процес, проблема вивчення особливостей та умов процесу формування професійної компетентності у майбутніх учителів історії має перспективи подальших досліджень.

\section{Література}

1.Адольф В.А. Профессиональная компетентность современного учителя: монография / КрГУ / В.А. Адольф. - Красноярск: КрГУ, 1998. - 286 с.

2.Афанасьєв Ю. Л. Соціально-культурний потенціал художньої діяльності / Ю. Л. Афанасьєв. - Львів: Світ, 1990. - 160 с.

3.Величко О. Г. Якість освіти - проблеми й перспективи / О. Г. Величко, С. Й. Пінчук, С.Т. Пліскановський // Проблеми освіти: наук.-метод. зб. - К.: 
Наук.-метод. центр вищої освіти, 2003. - Вип. 34. - С. 282-286.

4.Гершунский Б. С. Философрия образования / Б. С. Гершунский. - М.: “Флинта", 1998. - 492 с.

5.Гончаренко С.У. Український педагогічний енциклопедичний словник. Видання друге, доповнене й виправлене / С. У. Гончаренко. - Рівне: Волинські обереги, 2011. - 552 с.

6.Гриценко А. П. Психологічні аспекти формування інформаційнокомунікаційної компетентності у майбутніх учителів історії / Андрій Петрович Гриценко // Вісник Глухівського національного педагогічного університету імені Олександра Довженка. Сер. : Педагогічні науки. - 2018. - Вип. 3. - С. 58-65.

7.Гриценко А. П. Формування інформаційної компетентності майбутніми вчителями історії під час використання освітніх веб-сайтів та соціальних мереж / А. П. Гриценко // Професіоналізм педагога в умовах освітніх інновацій: матеріали II Міжнар. наук-практ. інтернет-конф. / Відповід. ред. О. Хващевська. Слов'янськ: Мінідрукарня «Папірус», 2018. - С. 281-284.

8.Державний стандарт базової і повної середньої освіти (Затверджено Постановою Кабінету Міністрів України від 23 листопада 2011 р. № 1392) [Електронний ресурс] // Законодавство України. - Режим доступу: https://zakon.rada.gov.ua/laws/show/1392-2011-\%D0\%BF. - Назва з екрану.

9.Зимняя И.А. Ключевые компетентности как результативно-целевая основа компетентностного подхода в образовании / И. А. Зимняя // Труды методологического семинара “Россия в Болонском процессе: проблемы, задачи, перспективы”, Москва: Исследовательский центр проблем качества подготовки специалистов, 2004. - 40 с.

10. Кара С.І. Формування професійної компетентності майбутніх вчителів початкових класів у процесі педагогічної практики: автореф. дис. на здоб. наук. ступеня канд. пед. наук : 13.00.04 / Кара Світлана Іванівна; Житомир. держ. ун-т ім. І. Франка. - Житомир, 2012. - 20 с.

11. Луговий В.ІІ. Національна рамка кваліфікацій: розуміння і реалізація / В. І. Луговий, Ж. В. Таланова // Проф.-техн. освіта. - 2010. - № 1. - С. 5-9.

12. Луговий В.І. Рамка кваліфікацій та система гарантування якості національної вищої освіти: труднощі реалізації / В. І. Луговий, О. М. Слюсаренко, Ж. В. Таланова // Вища освіта України. Додаток 4. - 2010. - С. 257-265.

13. Малієнко Ю. Б. Формування історичної компетентності засобами підручника з історії середніх віків / Ю.Б. Малієнко // Проблеми сучасного підручника. - 2016. - Вип. 16. - С. 203-212.

14. Маркова А. К. Психология профессионализма / А. К. Маркова. М.: Международный гуманитарный фонд “Знание", 1996. - 312 с.

15. Методичні рекомендації щодо розроблення стандартів вищої освіти [Електронний ресурс] // Сайт Міністерства освіті і науки України. - Режим доступу: https://mon.gov.ua/storage/app/media/vishcha-osvita/rekomendatsii-1648.pdf - Назва 3 екрану.

16. Національна стратегія розвитку освіти в Україні на період до 2021 року, затверджена Указом Президента України від 25 червня 2013 року № 344/2013 [Електронний ресурс] // Сайт Верховної Ради України. - Режим доступу: http://zakon.rada.gov.ua/laws/show/344/2013 - Назва з екрану.

17. Пометун О.І. Практика реалізації компетентнісного підходу в суспільствознавчих дисциплінах / О. І. Пометун, Г. О. Фрейман // Компетентнісний підхід у сучасній освіті: світовий досвід та українські перспективи: Бібліотека 3 освітньої політики / під заг. ред. О. В. Овчарук. - К. : “К.І.С.”, 2004. - С. 105-107.

18. Про затвердження Національної рамки кваліфікацій [Електронний ресурс] // Верховна Рада України. - 2011. - Режим доступу: 
http://zakon4.rada.gov.ua/laws/show/1341-2011-\%D0\%B - Загол. з титулу екрану.

19. Розроблення освітніх програм. Методичні рекомендації / За ред. В. Г. Кременя. - К.: ДП “НВЦ “Пріоритети”, 2014. - 120 с.

20. Савченко О.Я. Компетентнісний підхід як чинник якості професійної підготовки майбутнього вчителя / О.Я. Савченко // Формування ключових і предметних компетентностей молодших школярів у навчальному процесі: теорет. аспекти: дайджест 1 / Укл. О. В. Онопрієнко. - Донецьк: Каштан, 2011. - С. 15-22.

21. Семеног О. М. Сучасні інформаційні технології у професійній фрілологічній освіті: проблеми, пошуки, перспективи / О. М. Семеног // Зб. наук. пр. - Вип. 5 ; редкол.: І. А. Зязюн (голова) та ін. - Вінниця : ДОВВінниця, 2007. C. 631-638.

22. Таланова Ж. В. Освітні та професійні кваліфікації в національній кваліфікаційній системі на найвищому рівні освіти / Ж. В. Таланова // Безперервна професійна освіта в контексті європейської інтеграції: теорія, досвід, прогноз: зб. наук. ст. методолог. семінару.: у 2-х ч. - К. : Пед. думка, 2010. - Ч. 1. - С. 173-181.

23. Татур Ю. Г. Компетентность в структуре модели качества подготовки специалиста / Ю.Г. Татур // Высшее образование сегодня. - 2004. - №3. C. 20-26.

24. Хуторской А. В. Ключевые компетенции как компонент личностноориентированной парадигмы образования / А. В. Хуторской // Ученик В общеобразовательной школе. - М.: ИОСО РАО, 2002. - С. 135-157.

\section{References}

1.Adolf, V.A. (1998) Professionalnaia kompetentnost sovremennogo uchitelia: monografiia [Professional competence of a modern teacher: monograph]. Krasnoiarsk: KrGU [in Russian]/

2.Afanas'yev, Yu. L. (1990) Social’no-kul'turny`j potencial xudozhn`oyi diyal'nosti [Socio-cultural potential of artistic activity] L'viv: Svit [in Ukrainian].

3. Vely`chko, O. G. (2003) Yakist' osvity` problemy' j perspekty 'vy' [Quality of Education Problems and Prospects] In O. G. Vely'chko, S. J. Pinchuk, S. T. Pliskanovs`ky j - Problemy` osvity` nauk. metod. zb. K.: Nauk. metod. centr vy`shhoyi osvity. Vy`p. 34. (pp. 282-286) [in Ukrainian].

4.Gershunskii, B. S. (1998) Filosofiia obrazovaniia [Philosophy of education]. M.: "Flinta" [in Russian]

5. Goncharenko, S. U. (2011) Ukrayins `ky ` pedagogichny `j ency`klopedy`chny`j slovny'k. [Ukrainian Pedagogical Encyclopedic Dictionary], Vy'dannya druge, dopovnene j vy` pravlene. Rivne: Voly`ns`ki oberegy [in Ukrainian].

6. Gry`cenko, A. P. Psy'xologichni aspekty' formuvannya informacijnokomunikacijnoyi kompetentnosti u majbutnix uchy teliv istoriyi [Psychological aspects of the formation of information and communication competence in future teachers of history], Visny`k Gluxivs`kogo nacional’nogo pedagogichnogo universy`tetu imeni Oleksandra Dovzhenka. Ser. : Pedagogichni nauky`. (pp. 58-65) [in Ukrainian].

7.Gry`cenko, A. P. Formuvannya informacijnoyi kompetentnosti majbutnimy vchy ‘telyamy istoriyi pid chas vy kory 'stannya osvitnix veb-sajtiv ta social 'ny'x merezh [Formation of informational competence by future history teachers when using educational websites and social networks], Profesionalizm pedagoga v umovax osvitnix innovacij: materialy II Mizhnar. nauk-prakt. internet-konf. Vidpovid. red. O. Xvashhevs`ka. Slov'yans`k: Minidrukarnya «Papirus» (pp. 281 284) [in Ukrainian].

8. Derzhavny j standart bazovoyi i povnoyi seredn 'oyi osvity' [State standard of basic and complete secondary education] (Zatverdzheno Postanovoyu Kabinetu Ministriv Ukrayiny` vid 23 ly`stopada 2011 r. \# 1392) [Elektronny`j resurs] Zakonodavstvo Ukrayiny`. Rezhy'm dostupu: https://zakon.rada.gov.ua/laws/show/1392-2011-\%D0\%BF. - Nazva z 
ekranu [in Ukrainian].

9.Zimniaia, I.A. (2004) Kliuchevye kompetentnosti kak rezultativno-tcelevaia osnova kompetentnostnogo podkhoda $v$ obrazovanii [Key competencies as an effective target basis of a competence-based approach in education], Trudy metodologicheskogo seminara "Rossiia v Bolonskom protcesse: problemy, zadachi, perspektivy", Moskva: Issledovatelskii tcentr problem kachestva podgotovki spetcialistov [in Russian].

10. Kara, S.I. (2012) Formuvannya profesijnoyi kompetentnosti majbutnix vchy'teliv pochatkovy'x klasiv u procesi pedagogichnoyi prakty'ky'[ Formation of professional competence of future teachers of elementary school in the process of pedagogical practice] : avtoref. dy`s. na zdob. nauk. stupenya kand. ped. nauk : 13.00.04; Zhy` tomy`r. derzh. un-t im. I. Franka. - Zhy`tomy`r [in Ukrainian].

11. Lugovyうj V. I. (2010) Nacional'na ramka kvalifikacij: rozuminnya i realizaciya [National Framework of Qualifications: Understanding and Implementation] (pp. 5 9). In V. I. Lugovy j, Zh. V. Talanova, Prof.-texn. osvita [in Ukrainian].

12. Lugovy j, V. I. (2010) Ramka kvalifikacij ta sy`stema garantuvannya yakosti nacional'noyi vy'shhoyi osvity'[Qualifications Framework and Quality Assurance System for National Higher Education: implementation difficulties] : trudnoshhi realizaciyi (pp. 257-265). In V. I. Lugovy`j, O. M. Slyusarenko, Zh. V. Talanova Vy`shha osvita Ukrayiny. Dodatok 4 [in Ukrainian].

13. Maliyenko Yu. B. Formuvannya istory 'chnoyi kompetentnosti zasobamy pidruchny ${ }^{\prime} k a$ z istoriyi serednix vikiv [Formation of historical competence through the textbook on the history of the Middle Ages] (pp. 203-212), Problemy` suchasnogo pidruchny`ka. - 2016. - Vy`p. 16 [in Ukrainian].

14. Markova, A. K. (1996) Psikhologiia professionalizma [Psychology of professionalism]. M.: Mezhdunarodnyi gumanitarnyi fond "Znanie" [in Russian].

15. Metody`chni rekomendaciyi shhodo rozroblennya standartiv vy`shhoyi osvity [Methodical recommendations for the development of higher education standards] [Elektronny`j resurs], Sajt Ministerstva osviti i nauky` Ukrayiny`. - Rezhy`m dostupu: https://mon.gov.ua/storage/app/media/vishcha-osvita/rekomendatsii-1648.pdf - Nazva z ekranu [in Ukrainian].

16. Nacional'na strategiya rozvy 'tku osvity` $v$ Ukrayini na period do 2021 roku [National Strategy for the Development of Education in Ukraine for the period up to 2021], zatverdzhena Ukazom Prezy`denta Ukrayiny` vid 25 chervnya 2013 roku \# 344/2013 [Elektronny`j resurs]. Sajt Verxovnoyi Rady` Ukrayiny`. - Rezhy 'm dostupu: http://zakon.rada.gov.ua/laws/show/344/2013 - Nazva z ekranu [in Ukrainian].

17. Pometun, O. I. (2004) Prakty'ka realizaciyi kompetentnisnogo pidxodu $v$ suspil 'stvoznavchy' $x$ dy'scy 'plinax [Practice of implementing a competent approach in social sciences disciplines] (pp. 105-107) In O. I. Pometun, G. O. Frejman, Kompetentnisny j jidxid u suchasnij osviti: svitovy`j dosvid ta ukrayins`ki perspekty`vy: Biblioteka z osvitn`oyi polity 'ky' / pid zag. red. O. V. Ovcharuk. -K. : "K.I.S." [in Ukrainian].

18. Pro zatverdzhennya Nacional'noyi ramky' kvalifikacij (2011) [Approval of the National Qualifications Framework] [Elektronny’j resurs], Verxovna Rada Ukrayiny'. Rezhy'm dostupu: http://zakon4.rada.gov.ua/laws/show/1341-2011-\%D0\%B Zagol. z ty` tulu ekranu [in Ukrainian].

19. Rozroblennya osvitnix program. Metody`chni rekomendaciyi (2014) [Development of educational programs. Guidelines], Za red. V. G. Kremenya. - K.: DP "NVCz "Priory" tety" [in Ukrainian].

20. Savchenko, O. Ya. (2011) Kompetentnisny`j pidxid yak chy`nnyłk yakosti profesijnoyi pidgotovky' majbutn `ogo vchy telya [Competency approach as a factor in the quality of the future teacher's professional training], (pp. 15-22). Formuvannya klyuchovy'x i predmetny' $x$ kompetentnostej molodshy' $x$ shkolyariv $u$ navchal'nomu procesi: teoret. aspekty`: dajdzhest 1. Ukl. O. V. Onopriyenko. - Donecz`k: Kashtan [in Ukrainian]. 
21. Semenog, O. M. (2007) Suchasni informacijni texnologiyi u profesijnij filologichnij osviti: problemy', poshuky', perspekty 'vy' [Modern information technologies in professional philological education: problems, searches, perspectives] (pp. 631-638), Zb. nauk. pr. - Vy’ 5 ; redkol.: I. A. Zyazyun (golova) ta in. - Vinny cya: DOVVinny`cya [in Ukrainian].

22. Talanova, Zh. V. (2010) Osvitni ta profesijni kvalifikaciyi v nacional'nij kvalifikacijnij sy'stemi na najvy'shhomu rivni osvity [ Educational and professional qualifications in the national qualification system at the highest level of education] (pp. 173181), Bezperervna profesijna osvita $v$ konteksti yevropejs'koyi integraciyi: teoriya, dosvid, prognoz: zb. nauk. st. metodolog. seminaru.: u 2 x ch. K. : Ped. Dumka. Ch. 1. [in Ukrainian].

23. Tatur, lu. G. (2004) Kompetentnost $v$ strukture modeli kachestva podgotovki spetcialista [Competence in the structure of a specialist training quality model], ( $p p$. 20-26) Vysshee obrazovanie segodnia. №3 [in Russian].

24. KHutorskoi, A. V. (2002) Kliuchevye kompetentcii kak komponent lichnostno-orientirovannoi paradigmy obrazovaniia [Key competencies as a component of the student-centered education paradigm], (pp. 135-157) Uchenik v obshcheobrazovatelnoi shkole. - M.: IOSO RAO [in Russian].

\section{АНОТАЦІЯ}

Автор у поданій статті аналізує основні теоретичні положення умов формування профресійної компетентності майбутніх учителів історії та представляє головні підходи, що склались у сучасній педагогічній та психологічній літературі. Звернено увагу на відмінності двох взаємопов'язаних понять "компетентність" та “компетенція", а також представлено трискладову структуру системи компетентностей в освіті, що включає ключові чи базові, загально-галузеві та професійно-спеціалізовані (предметні) компетентності, які набуваються впродовж вивчення тієї чи іншої навчальної дисципліни та подано визначення терміна "профресійна компетентність".

У статті головними ознаками профресійної компетентності виділено: необхідність формування знань за умови усвідомлення їх значущості для майбутньої професійної діяльності, набір операційних умінь; напрацювання алгоритму виконання профресійних вправ та здатність до творчості під час виконання професійних завдань. Це дало можливість визначити умови, за яких відбувається фрормування професійної компетентності в майбутніх учителів під час їхньої неперервної та системної діяльності за наявності у них відповідних профресійних якостей, що сприяють цій діяльності, та загальних здібностей, які грунтуються на знаннях, досвіді, цінностях, набутих завдяки навчанню, вихованню, інтеграції у простір соціальних і культурних відношень.

Крім того, розглянуто психологічні аспекти фрормування в студентів закладів вищої освіти означеної компетентності, що дозволяє значно покращити результативність освітнього процесу підготовки майбутніх фахівців, який супроводжує засвоєння теоретичних основ, засобів $і$ методів виконання професійних завдань; уміння аналізувати, прогнозувати свою діяльність та самостійно обирати засоби та способи дії в певних конкретних ситуаціях; здатність до саморозвитку та самореалізації за умов опанування сучасних наукових досягнень та їх упровадження і позитивного ставлення до своєї майбутньої професійної діяльності.

Ключові слова: компетентнісний підхід, історія, компетенції, профресійна компетентність, майбутні вчителі, професійна підготовка, профресійні освітні кваліфрікації. 